\title{
A REGIONÁLIS INNOVÁCIÓ ÉS A HELYI NYILVÁNOSSÁGOK FELÉRTÉKELŐDÉSE ${ }^{1}$
}

\author{
(Regional Innovation and the Consolidation \\ of Local Public Spheres)
}

SZÍVÓS MIHÁLY

\begin{abstract}
Kulcsszavak:
tágabb értelemben vett regionális innováció helyi nyilvánosság civil szféra hallgatólagos tudás földrajzi és társadalmi mobilitás helyi döntési folyamat regionális identitás

A tanulmány kiindulópontja a helyi nyilvánosságok tartós megerősödésének jelensége, amely a demokrácia helyi intézményrendszerének kiépülésére, azon belül pedig elsösorban a civil szféra megerösödésére, valamint a regionális fejlödés állami és uniós támogatására vezethetö vissza. A helyi témák iránti növekvő érdeklödést tanúsítja a helyi lapok, internetes fórumok, rádióadók megerösödése az országos napilapok, fórumok és adók rovására. A település-és régiófejlesztési céllal létrejött civil szervezetek belenőttek a helyi politikai életbe az országos pártok befolyásának rovására, és támogatott jelöltjeiket be tudják juttatni az önkormányzati testületekbe. A helyi nyilvánosság e jelenségekben megmutatkozó kibontakozása és megerösödése előmozdítja a kisebb-nagyobb térségek jövőjét formáló gazdasági és társadalmi erök egymásra találását, vitáikat és a konfliktusok kihordását, valamint az együttmüködést is. A helyi nyilvánosság e jelentős mértékü felértékelödése megalapozza a települések és a régiók jövöjének az ott lakók által történö formálását és az ehhez szükséges, tágabb értelemben vett regionális innováció kiérlelését és megvalósítását, beleértve a gazdasági és kulturális identitás meghatározását is. A tanulmány tárgyalja a munkát kereső és a felsőoktatásban részt vevő fiatalok földrajzi és társadalmi mobilitásának a tágabb értelemben vett regionális innovációra gyakorolt hatásait is, különös tekintettel a kisebb és nagyobb régiókban kialakuló fejlödési központok megerösödésére és innovatív szerepére. A helyi nyilvánosságok megerösödésének, valamint a fejlödési és innovációs központok létrejöttének és müködésének fontos kíséröjelensége az explicit és a hallgatólagos tudás áramlása és felhalmozódása, amit a kétféle mobilitás jelentősen elösegít.

A nyilvánosság tehát maga is értékes eröforrás, amely más eröforrásokhoz hasonlóan szükösen áll rendelkezésre.
\end{abstract}

(Angelusz 2000a)

E tanulmány elsődleges célja az, hogy a tágabb értelemben vett regionális innováció feltételeit és folyamatait a helyi nyilvánosság megerősödésének kontextusában elemezze, és így szociológiai síkon hozzájáruljon a regionális innovációról alkotott közgazdasági ihletésü elemzések kiegészítéséhez.

A regionalizmus megerősödése hazánkban a rendszerváltozás után kapott először igazán szabad teret a demokrácia kiépítésével együtt járó politikai decentralizációval. Különösen fontos tényezővé vált a helyi önkormányzatok tevékenységének kibontakozása és a helyi civil szféra kiépülése és megerősödése annak ellenére, hogy az erőforrások elosztása nagyrészt továbbra is központosított maradt, illetve a regionális politika még a múlt század kilencvenes éveiben is meglehetősen szük 
eszközkészlettel müködött. A regionalizmus állami és uniós politikájának, a helyi önkormányzatok, a vállalati szféra, valamint a vidéki tudáscentrumok fejlődésének összefüggéshálójában már világosan látható, hogy a helyi nyilvánosság kiszélesedése és a véleménynyilvánítási kedv megerősödése logikus módon követte ezt a kibontakozást. A helyi nyilvánosságoknak, akárcsak a széles, országos kiterjedésủ társadalmi nyilvánosságnak, megvannak a maguk alapfeladatai, amelyek mellett még a tudás sajátos formáinak közvetítéséhez is hozzájárulnak, és ezáltal is elösegítik a társadalmi és szervezési innováció kibontakozását. Egyebek mellett ez teszi őket értékes gazdasági és társadalmi erőforrássá.

A regionális müszaki-technológiai innováció kérdéskörét a szerzők többsége szorosan összekapcsolja az adott régióban levő egyetem vagy föiskola tudományos kapacitásával, a tudományos fokozattal rendelkező oktatók és kutatók számával, valamint a fejlett, a legújabb tudományos eredményekre épülő technológiákat kezelö vállalatok megalapításával, illetve a régióba való betelepülésükkel és ottani müködésükkel. Az egyetemi kutatások keretében zajló innováció mellett a vállalati környezettel való müszaki együttmüködés, a fejlesztés, valamint a szervezési és informatikai újítások bevezetése számít az innováció fő területének. Létezik viszont az innovációnak egy tágabb, a szociológiailag leírható összefüggések irányában kibővített értelmezése, amely a fentieken túlmenően mindenekelőtt a regionális szereplők, a lakosság, az önkormányzat, a vállalatok, a sajtó, a közoktatási intézmények, a civil szféra egyesületei közötti együttmúködés megújítását, új formáinak kitalálását és bevezetését jelenti. Az innovációnak ez a kibővített értelmezése magában foglalja a szükebb, technológiai értelmezést is, még abban a tekintetben is, hogy gyakran egy jelentős müszaki, informatikai találmány elterjedése (mobiltelefon, internet) indít el olyan fejlődést, amely a fenti szereplők közötti viszonyokat alapvetően átalakíthatja és megújíthatja. Ilyenné vált például az internetes vagy mobiltelefonos ügyfélbejelentkezés az önkormányzatokhoz és az elektronikus levelezés az ügyfelekkel.

A helyi nyilvánosság erősödése a rendszerváltás utáni időszakban folyamatosnak mondható. Ekképpen még akkor is tartott, amikor a nagyobb léptékü regionális programok megjelentek, amelyek a különféle tervek felvetésével, előkészítésével és értékelésével helyi körökben közfigyelmet keltettek. A tervek kialakulásával és megvalósításuk elkezdésével a helyi nyilvánosság közvetítése révén tovább folytatódott az, amit a helyi gazdaságpolitikai és gazdasági profil kialakulásának és megerősödésének folyamataként jelölhetünk meg, és amely elvezet a regionális gazdasági és társadalmi identitás újrafogalmazásához.

A helyi nyilvánosság kibontakozása és megerősödése nemcsak önmagában érték és a helyi demokrácia megerősödésének a jele, hanem kiemelkedő jelentőségű a kisebbnagyobb térségek jövőjét formáló gazdasági és társadalmi erők egymásra találása, vitái és konfliktusai, valamint együttmüködésük szempontjából is. A földrajzi és gazdasági helyzetekből eredő kényszerpályák, szükségszerü folyamatok elemzése mellett a regionális tudományok szakirodalmában ugyanis gyakran hangoztatják azt, hogy a helyi erőknek, a helyi polgároknak együttmüködve kell rátalálniuk azokra a megoldásokra, amelyek a legjobban képesek biztosítani az adott térség jövőjét (pl. Bartke 
2007, 738). Ez az egymásra találás és a közös célok innovatív szellemü megfogalmazása, elfogadása és megvalósítása nem mehet végbe a helyi nyilvánosság közvetítő tevékenysége nélkül. Ebben a tekintetben a helyi nyilvánosságok részben szakmai nyilvánosságként funkcionálhatnak, ahol a helyi érdekeket artikulálva végül - optimális esetben - a szakszerüség szempontjai is erősen érvényesülhetnek. Az ilyen típusú nyilvánosság megerösödése előnnyé válhat és az együttmüködési hatékonyságot javító kapacitása folytán egy adott régió gyengébb infrastrukturális feltételeit bizonyos mértékig ellensúlyozhatja a hatékonyabb együttmüködés elömozdításával.

A helyi nyilvánosságok felértékelődése, valamint a régiók gazdasági megerősödése - egyebek mellett éppen a helyi nyilvánosság közvetítő tevékenysége segítségével elöre mutat az igazi policentrikus fejlödés kibontakozása felé. A helyi közösségek által elfogadott és támogatott regionális fejlesztési programok éppen az ilyen többközpontú, fejlett, tudásalapú társadalomnak lehetnek a biztosítékai.

\section{A helyi nyilvánosság megerősödése}

A nyilvánosságnak a szociológiai szakirodalomban számos meghatározása ismert, amelyek összefoglalása helyett itt a nyilvános szónak abból az egyszerü jelentéséből indulunk ki, hogy nyilvános az, ami általánosan elérhető. Ebből következően a nyilvánosság elsődlegesen olyan társadalmi tér, amelyben a közérdekủ tények, a taglalt témák, az érvek és az álláspontok általánosan elérhetőek és hivatkozhatóak, illetve vélemény, kritika és kiegészítés fogalmazható meg velük kapcsolatban. A nyilvánosságon belül szükséges megkülönböztetni az alanyi és tárgyi oldalt, amit a szakirodalomban gyakran elmulasztanak (Angelusz 1983, 26). A közvéleményt azután egészen általánosan, a nyilvánosságra vonatkoztatottan, mint eme alanyi és tárgyi oldal közötti viszonyt határozzuk meg. A nyilvánosság szó a magyar nyelvben kettős jelentésü, mert egyszerre jelenti az előbb említett nyilvános teret, amelybe az általánosan elérhetö tények, témák, vélemények bekerülnek, és azt a közönséget, amely elé mindezek kerülnek, és amely azokat megítéli. Ez a kettősség - gyakran reflektálatlanul megjelenik a szakirodalomban található leírásokban is.

A nyilvánosságot tárgyalva a szakirodalom nagyobb részében gyakran kihagynak egy nagyon fontos, bár korántsem evidens funkciót: a közvetítést. A társadalmi nyilvánosság eszerint nemcsak az állammal szembeni kritikai és ellenőrző intézmény, hanem közvetítő társadalmi közeg is ennek az államnak a hatalmi ágai, valamint szervezeti egységei között. A sajtónyilvánosság például így közvetít a független bíróságok tevékenysége és a törvényhozói ág között, ekképpen segítve mind a törvényhozók és a velük dolgozó szakértők, mind pedig a bírák és más jogászok tevékenységét. A helyi nyilvánosságnak a nyilvánvaló ellenőrző funkcióin túlmenően ugyanígy vannak jelentős közvetítő funkciói is a különféle hatalmi ágak helyi szervei, valamint a közélet más intézményei között. A helyi sajtó például közvetít a polgárok és a választott testületek között, miközben e viszony mindkét pólusa felé kritikai funkciókat is ellát. A nyilvánosság közvetítői funkciójának intenzitása nyilvánvalóan erősebb a regionális központokban, ahol számos szervezet irányító egységei müködnek. 
A rendszerváltás utáni időszakban az új demokratikus formák normális müködésének kibontakozásával a helyi nyilvánosság megerősödése és felértékelődése elkezdődött és - némileg lelassult ütemben - napjainkban is folytatódik. Ennek keretében a helyi lakosság figyelme növekvő mértékben a helyi ügyekre, a helyi konfliktusokra, a helyi választásokra és a helyi döntéshozókra irányul. E folyamat színterei elsősorban a főváros közvetlen vonzáskörzetén kívüli régiók voltak, de a helyi nyilvánosság megerősödése még Budapest egyes kerületeiben is észlelhető volt és jelenleg is tapasztalható. Mindez fontos mutatója a lakossági aktivitás növekedésének is, ami egyben a helyi életvilághoz kapcsolódó témák nyilvános felvetésének erősödését is magával hozta. Az önszervező erők fellépése már önmagában a helyi nyilvánosság formálódásának egyik nagyon fontos aktusa volt, és nemcsak annyiban, hogy a nyilvánosság társadalmi terét kitágította és a közbeszéd lehetséges témáit felszaporította, hanem annyiban is, hogy a nyilvánosság közönségének aktív, reflektáló részét gyarapította.

A helyi nyilvánosság kibontakozásához a civil társadalom megszerveződése, a különféle társaságok, egyesületek, érdekvédelmi szervek megalapítása ugyancsak tetemesen hozzájárult. A civil társadalom szervezetei kialakították tevékenységi célterületeiket és megfogalmazták cselekvési programjaikat. A selejteződési folyamat során az életképesek megmaradtak, miközben az olyan programok, amelyek mögött csak gyenge aktivitás mutatkozott, teljesen el is sorvadtak. A nonprofit szervezetek egyik igen fontos csoportja, éspedig a településfejlesztési célú nonprofit szervezetek statisztikája azt mutatja, hogy a kilencvenes évek végéig folyamatosan növekedett e szervezetek száma, sőt ezen felül még a részarányuk is növekedett az e kategóriába tartozó szervezetek között (Mészáros 2002, 17). Az elektronikus közigazgatás, vagyis az internet bevonása a helyi ügyek intézésébe csak tovább erősítette a már megindult folyamatokat. A helyi közigazgatás honlapjai ugyanis nemcsak ügyintézési, hanem gyakran hírközlési, elemzési, sőt párbeszédes portálokként is müködnek. A civil szervezetek honlapjainak jelentős része ugyancsak sokrétü. Még az ipari és szolgáltatóipari vállalatok honlapjai is hozzájárultak az informatív nyilvánosság megerősödéséhez és a gazdasági élet átláthatóbbá tételéhez.

A helyi nyilvánosság egészséges kibontakozását az integráció keretében megtámogatta az Európai Unió regionális politikája is már a csatlakozás előtti időszakban. A nagyobb régiók és kistérségek támogatása, a sikeres pályázatok és a létrehozott eredmények megpezsdítették a helyi közvéleményt és a csatlakozás utáni újabb programok, különösen, ha azok széles körü előkészítő munkával párosulnak, ugyancsak hasonló hatást váltanak ki. A fejlesztési terveket előkészítő időszak egyik sajátossága, hogy számos téma bekerül a nyilvánosságba és a viták során a közvélemény alanyai tájékozottabbá válnak saját lakó- és munkakörnyezetük sajátosságait, problémáit és távlatait illetően, illetőleg a nyilvánosságra hozott fejlesztési elképzelésekkel kapcsolatosan megfogalmazódnak a lakossági elvárások és az esetleges módosítási javaslatok. E kontextusban is fontossá válnak a hosszú távra szóló regionális fejlesztési programok, amelyek ily módon a regionális innováció fellendítéséhez is hozzájárulhatnak. 
A helyi nyilvánosság megerősödését az írott sajtó területén elsődlegesen jól mutatja az, hogy az országos napilapokat jóval kisebb számban rendelik meg az egyes régiókban ${ }^{2}$, illetve vásárolják az újságos standoknál, mint a helyi napilapokat ${ }^{3}$. Ez a változás már az ezredforduló idején befejezett tény volt. A megyei és regionális lapok megrendelése és vásárlása továbbra is fölülmúlta az országos lapokét, olykor enyhe mértékben emelkedve, de legalábbis nem csökkenve egy olyan időszakban, amikor az országos lapok az internettel és más fórumokkal szemben már teret veszítenek ${ }^{4}$. De nemcsak az írott sajtóval kapcsolatosan mutatható ki ez a tendencia, hanem a helyi rádióadók hallgatottságában is megmutatkozik. Egy 2007 elején végzett felmérés eredménye szerint a hazai helyi rádiók hallgatottsága egészében véve nagyobb mérvü, mint az országos adókés .

Egyes regionális újságok alkalmazkodtak ehhez a helyzethez és a napilapoknak a kisrégiók lakosságát megcélzó mellékleteik vagy akár időszakosan megjelenő betétlapjaik vannak, amelyek egy-egy kisebb térség híreit szedik csokorba. A kisebb térségben ugyanis szintén igény van az egészen helyi hírek megjelentetésére és értékelésére, és a helyi önkormányzat szándékainak, terveinek megismerésére és általában a helyi hírekre.

A nyilvános megszólalás és vita írott sajtón kívüli formái is tanúsítják a helyi nyilvánosság megerősödését, hiszen szaporodnak a helyi internetes újságok és az interaktív fórumok. Erre válaszolva egyébként a regionális újságok is létrehozták a saját internetes változataikat. Nagyon jelentős fejlemény, hogy az internet révén a lapalapítás, mármint elektronikus lapok alapítása sokkal könnyebbé vált, ami a sajtószabadság új dimenzióját nyitotta meg. E kisebb lapok úgy próbálnak megkapaszkodni a piacon - új szolgáltatást kínálva -, hogy mélyebb merítésủ elemzéseket készítenek helyi ügyekről és gyakran kritikusabb hangot ütnek meg, mint a regionális lapok, mivel hírforrásokként nem versenyezhetnek velük, miként a nagyobb portálokkal sem, sőt híreik javarésze is azoktól származik, mert azoknak állandó tudósítóik is vannak. Ezért a hírháttér-feltáró tevékenységükkel próbálnak szélesebb körủ olvasottságra, illetve internetes látogatottságra szert tenni. Ha nem is beszélhetünk a helyi nyilvánosság telítettségéről, az azonban kétségtelen, hogy a fejlődést az írott sajtó mellett az internetes portálok és a helyi médiák is követni próbálják, és szolgáltatásaik köre bővül. Az internetes újságok és portálok révén a gazdasági jellegü információk terjesztése ugyancsak sokat nyert. A tökehiány mindazonáltal itt is, miként a vidéki gazdaság más szektoraiban, erősen érezteti a hatását.

A helyi médiák arculatának átalakulása követte, sőt a nyugat-európai tulajdonosok megjelenése miatt több vonatkozásban meg is elözte a helyi nyilvánosságok átalakulását. A hasonló folyamatok Nyugat-Európában - nem utolsósorban az Európai Közösségeken belül bekövetkezett decentralizálás következményeképpen -, már jóval korábban végbementek. Következésképpen a helyi sajtó az új tulajdonosi struktúrában már részben az ott kialakult témaválasztási és lapszerkesztési elveket érvényesítette, 
és a politikai tartalmú közlemények és elemzések mellett egyre nagyobb teret kaptak a helyi közélet politikamentes aspektusai. Ily módon a megyei és regionális lapok jelentős része az újságírói zsargon szerint „desszertlapokká” változott.

A sajtó további átalakulását jelentősen befolyásolta a helyi közbeszéd megerősödése és spontaneitása. Az egyes közösségekhez szóló helyi sajtóban a szerzők már részben azokhoz szólnak, akiket személyesen is ismernek. A megszólalási küszöb ezáltal lejjebb került, és mind többen voltak hajlandók megszólalni, illetve igényelték a helyi közönség számára való megnyilatkozás lehetőségét. A helyi írott és elektronikus sajtó így közelebb került a báziskommunikációhoz, amely a közvéleményformálódás táptalaja (Angelusz 2000b, 68). Ilyen körülmények között a beszélő pozicionálása, illetve véleménynyilvánítása lényegesen kisebb nekikészülődést igényel és jóval kisebb kockázattal jár. E téren még vannak jelentős belső tartalékok és kibontatlan energiák, amelyeknek különösen az internet adhat teret.

A helyi médiákhoz való hozzáállás megváltozása, a helyi demokrácia és kritika megerősödése új szolgáltatások megjelenését is támogatta. E szolgáltatások egyik legfontosabb ágává nőtte ki magát a közügyekkel foglalkozó SMS üzenetek küldése, fogadása és publikálása. Viszonylag új fejlemény, hogy még a megyei, regionális lapokban is teret adnak az SMS küldőknek, akik egyrészt információkat közölnek, másrészt véleményt nyilvánítanak. Az SMS küldők nemcsak a fiatalok közül kerülnek ki, hanem a középkorúak is kiveszik ebböl a részüket. A tágabb értelemben vett regionális innováció egyik fontos példája ez, ahogyan az egyes lapok, felismerve az új kommunikációs forma jelentőségét és egyben nyilvánosságtágító szerepét, új rovatot vezettek be a mobiltelefonokról küldött SMS üzenetek számára. A helyi sajtó e gyors fejlődésének eredményei jól példázzák a tágabb értelemben vett regionális innovációt is.

Az egyik empirikus kutatás keretében a nagyrégiós központnak kiválasztott egyetemi városokban vizsgáltuk három kiemelkedően fontos helyi cselekvő szereplő (társadalmi aktor) - a polgármesteri hivatal, a helyi egyetem vezetése és a legjelentősebb helyi újság vezetősége - egymáshoz való viszonyát is ${ }^{6}$. E kapcsolatrendszereknek a helyi nyilvánosság szempontjából való elemzése elsődlegesen azt igényelte, hogy áttekintsük a városi adminisztrációnak és az egyetemi vezetésnek e nyilvánossághoz való viszonyát, majd ezután feltárjuk azt, hogyan látja e viszonyokat a helyi sajtó. Miközben a városi vezetés a helyi választások és a lakossági ellenőrzés miatt tudatosan és nagyon szervezett módon viszonyul a helyi sajtóhoz, addig az egyetemekröl nem mondható el az, hogy teljesen kihasználnák az ebben rejlő lehetőségeket, illetve hogy a nyilvánosságon keresztül is jelentős mértékben formálnák más helyi szereplőkhöz való viszonyukat. Kétségtelen viszont, hogy ez utóbbi attitüd változóban van két fontos tényező miatt. Az első az, hogy a központi kormányzat erösebben szorgalmazza az egyetemek innovációs szerepének megerősítését a regionális kapcsolatrendszer kibontakoztatásán keresztül. A másik tényező abból a demográfiai hátterủ problémából ered, hogy az egyetemi hallgató korú fiatalok létszáma országos szinten csökken és a jövőben tovább fog csökkenni, tehát az egyes egyetemek élesebb versenyhelyzetbe kerülhetnek a leendő hallgatók megnyerése 
végett, és ezért nagyon indokolt lehet számukra a helyi nyilvánosságban való átgondolt, hosszabb távra megtervezett és jól megszervezett jelenlét. E helyzetben kínálkozik az a megoldás, hogy az egyetemek jobban támaszkodjanak a helyi nyilvánosság eszközrendszerére azért, hogy fokozzák a nyilvánosságban való jelenlétüket az egyetem nyújtotta lehetőségek széles körü megismertetése, a tehetségek gondozására való képességük bemutatása végett. Egy adott régióban alighanem az egyetem tehet a legtöbbet a tehetséges emberek ottani megtartása érdekében.

\section{A helyi településfejlesztési célú nonprofit szervezetek eloszlása és hatása}

A regionális tudományok szakirodalmában, mint fentebb már utaltunk rá, régóta hangsúlyozzák annak fontosságát, hogy a régió szereplöi maguk döntsenek a létüket, jövőjüket érintő választási lehetőségeket illetően és ezáltal maguk szabják meg a fejlesztések további irányait. Ehhez nélkülözhetetlen erőforrás a helyi társadalmi nyilvánosság is, amely nem pusztán a helyi demokrácia kiteljesedését jelenti, hanem új szakaszt nyithat meg a tágabb értelemben vett regionális innováció területén is. A jól müködő önkormányzat mellett az innovatív megoldásokhoz fejlett civil társadalomra is szükség van. Az egyesületek, érdekvédelmi szervek ma már jelentős mértékben bele tudnak szólni a helyi politika, gazdaság és kultúra ügyeibe, sőt a helyi választásokon az általuk támogatott jelölteknek jelentős támogatást tudnak adni. Igen sok településen a civil társadalom jelöltjei már jelentös arányban kerülnek be az önkormányzatok vezető testületeibe, de a nagyobb városokban is jutnak mandátumhoz pártonkívüli jelöltek. Országos viszonylatban ma már a polgármesterek többsége sem valamely politikai párt jelöltjeként kerül be a hivatalába. Ez ugyancsak világosan mutatja a civil szervezetek fölemelkedésén túl azt is, hogy a helyi nyilvánosság felértékelődött, mert a civil szervezetek ennek révén is képesek akár választási témákká emelni programjaik arra alkalmas részeit, illetve maguk iránt elkötelezni a választókat, valamint a leendő önkormányzati vezetők egy részét, beleértve a polgármestereket is.

Jelenleg már e civil szervezetek hálózatosodásának, azaz többoldalú kapcsolatteremtésének és együttmüködésének szakaszában vagyunk. Országos vagy nagyrégiós ernyőszervezetek alakulnak, sőt esetenként már nemzetközi kapcsolatrendszerek jönnek létre, melyek elősegítik az együttmüködést és a közös érdekvédelmet. Ennek következtében a civil szervezetek kívánságai és javaslatai már rendszerezettebb formában jutnak el az önkormányzatokhoz és más döntéshozó fórumokhoz. A civil szervezetek és az önkormányzatok mélyebb együttműködésének immár múltja van, és a közös tapasztalatok megkönnyítik a további együttes munkálkodást. Ezen egyesületek, mint fórumok, maguk is a helyi és regionális nyilvánosság részeit képezik, és ezért a továbbiakban jelentős kezdeményezői lehetnek a kívánatos regionális együttmüködéseknek

Az önkormányzatok és a civil szervezetek közötti kapcsolatrendszer éppen az utóbbiak helyi választási sikerei miatt ma már számos helyen fejlettnek mondható, 
és ebben jelentős innovációs potenciál rejlik. De kívánatos lenne a helyi egyetemekkel való szorosabb együttműködésük (ahogy erre számos példa van föleg a környezetvédelemmel foglalkozó civil szervezetek körében). A civil szervezetek közremúködése a helyi ügyek irányításában azért is fontos, mert a választási időszakokban megjelenő önkormányzati programok szükségszerüen korlátozottak és elnagyoltak, részben a fejlesztéshez szükséges források bizonytalansága miatt, részben pedig amiatt, hogy a lakosság egyes ügyekben érintett részének véleményét, hozzáállását még nem ismerik eléggé, és ezért óvakodnak a terveket részletesebben kidolgozni. E civil szervezetek számon kérik a programok megvalósítását is, illetve közremüködnek azok részletekbe menő kialakításában.

\section{Térbeli és társadalmi mobilitás, valamint a generációs összetétel eltolódásai}

A helyi lakosság generációs összetétele igen fontos tényező a regionális innováció szempontjából. Ezért pusztán közgazdasági és gazdaságföldrajzi eszközökkel nem lehet kellő pontossággal felmérni egy adott régió innovációs potenciálját. Ismeretes, hogy a fiatalok eltávozása egy adott területről összefügg az innovációnak az ottani elmaradásával, vagy lelassulásával, illetve, az érme másik oldalaként, az elvándorlási célpontokban történő fellendülésével. A tudásintenzív gazdaság jobban igényli a fiatalabb munkaerőt, mivel az a felsőoktatás keretében már eleve megszerezte, vagy munka közben könnyebben meg tudja szerezni az újfajta tevékenységekhez szükséges tudást, valamint nyelvtudással és számítástechnikai ismeretekkel rendelkezik. Mivel a tudásintenzív tevékenységek az elvégzett vizsgálatok szerint térben koncentrálódnak (Lengyel 2007, 750), ezért ez a lakosságnak és ezen belül föleg a fiatalabb generációknak és a magasabb képzettségü rétegeknek a városokban, illetve a nagyvárosok körüli agglomerációkban való koncentrálódásával jár.

A lakosság elöregedése, amelyet a fiatalok további elvándorlása egyes térségekben radikálisan felgyorsíthat, mint ahogy az például Békés megyében is történik ${ }^{7}$, nemcsak a foglalkozási szerkezet kedvezőtlen megváltozásához, hanem túlzott konzervativizmushoz vagy egyenesen bezárkózottsághoz vezethet. Különösen a magasabban képzett fiatalok mennek el a falvakból és olykor még a kisebb városokból is, a leggyakrabban azért, mert a nagyobb városokban munkahelyek szélesebb választékát találják. Nem jelentéktelen vonzerőt képvisel a szélesebb körü, gazdagabb fogyasztási kultúra. A földrajzi mobilitás tehát gyakran elválaszthatatlan a társadalmi rétegek közötti mobilitástól, mert az előbbire gyakran azért kerül sor, hogy az utóbbi az új, kedvező feltételek között bekövetkezhessék. A fiataloknak ez a beáramlása a régióközpontokba és a nagyobb, egyetemi városokba, mint a térbeli mobilitás felgyorsulása és az ezzel járó felfelé irányuló társadalmi mobilitás a vele összekapcsolódó problémák miatt ott önmagában is nyilvánosságélénkítő hatású. A beáramlás és felemelkedés helyén megerősíti a társadalmi innováció iránti szükség- 
letet, illetve az arra való hajlamot. Jól mutatja ezt a vidéki egyetemi városok szellemi élete, az új iránti fogékonyság terjedése, amelynek egyik fontos mutatója a modern művészeti alkotások elfogadása vagy éppen sikere. A generációk közötti természetes demográfiai arányoknak e megváltozása, illetve eltolódása a fiatalok javára a tágabb értelemben vett regionális innováció egyik legfontosabb forrása és táplálója, mert nemcsak általában a világnézet szintjén, hanem a munkaerőpiacon és az oktatásban is az újdonság keresésének és elfogadásának irányába hat. A fiatalok kétféle mobilitása elősegíti azt, hogy kialakuljon az a kritikus tömeg, amely szükséges a helyi innovációs folyamatok megindításához és fenntartásához, miközben távozásuk a gyenge vagy majdnem semmilyen fejlődési potenciállal rendelkező kisrégiókból éppenséggel az újítások egyik fö akadálya lesz.

A helyi közélet enerváltsága vagy éppen kilátástalansága sem elhanyagolható tényező az elvándorlás kiváltásában. A megfelelő munkahelyek, mint elsődleges fontosságú megtartó tényezők mellett a helyi nyilvánosság müködése és a kulturális szolgáltatások elérhetősége különösen fontos a fiatalok megnyerése és megtartása szempontjából. A pezsgő nyilvánosság teret adhat a kezdeményezésnek, majd a tervezésnek és az újítások kidolgozásának, ami a társadalmi felemelkedés ígéretét is inkább magában hordozhatja.

Az egyetemek hallgatói létszámának folyamatos növekedése a rendszerváltás utáni időszakban egészen az összlétszám megnégyszereződéséig jelentős nyilvánosságmódosító hatással is járt a vidéki egyetemi városokban, mivel az így bekövetkezett mobilitás e városok lakosságának összetételét is megváltoztatta. Az itteni fiatalság, amely sajátos szubkultúrájával megjelenik az egyetemi város belső - építészeti, intézményi és társadalmi - terein, gyengíti a tradicionalizmusra való hajlamot és az életmódbeli konzervativizmust, tehát olyan fontos tényezőket, amelyek a tudástársadalom kibontakozásának akadályai.

A nagyrégiók központjaiban a korfa felső részének eltolódása a fiatalabb generációk miatt a rájuk jellemző kommunikációs formák előtérbe kerülését eredményezi, miként hangsúlyosabban jelennek meg a médiákban azok a tartalmak is, amelyek őket jobban foglalkoztatják, és ízlésük szerint módosul a helyi fogyasztási struktúra. A tartalmak terén talán az a legfontosabb változás, hogy a tervek a fiatalabb korosztályok miatt hosszabb távra fogalmazódnak meg, illetve éppen a hosszabb távra szóló egyéni élettervek miatt ezek a rétegek több változást, több innovációt várnak el társadalmi környezetüktől, a helyi adminisztrációtól és egyéb intézményektől, de a saját rétegüktől is.

\section{Tudásáramlás, hallgatólagos tudás, nyilvánosság és innováció}

A régiók és a városok közötti, illetve a régión belüli tudásáramlás jelentős részben a földrajzi mobilitás révén valósul meg. E mobilitás legjelentősebb formája a megfelelő oktatási helyek felé való törekvés, illetve az eredeti lakhelyre való visszatérés vagy új lakhely választása a már megszerzett tudással. A szakképzés, mint fentebb 
utaltunk rá, önmagában egyszerre vált ki földrajzi és társadalmi mobilitást, ami a diplomák megszerzése után ismét újabb földrajzi és társadalmi mobilitáshoz vezet, immár a megfelelő képzettségi szintet igénylő és ennek megfelelő bérezést kínáló munkahelyek felé, másrészt hozzájárul az érkeztető helyi társadalom összetételének fokozatos módosulásához is. A tudástársadalom ambiciózus programja és az élethossziglani tanulás gazdasági szükségletének érvényesülése azt vetíti előre, hogy a térbeli és a társadalmi mobilitás egyaránt erősödni fog, ami a tágabb értelemben vett innovációnak újabb impulzusokat adhat.

A regionális centrumokat mindenekelőtt az az öt vidéki nagyváros alkotja, amelyeknek mint a föváros ellenpólusainak a fejlesztésére koncentráltak a hatvanas évektől a nyolcvanas évekig (Rechnitzer 2007, 698), és amelyek megmaradtak e funkciójukban (Beluszky 2007, 728). E nagyvárosok agglomerációja tovább fog nőni (Rechnitzer 2007, 696-698) és folytatódnak bennük és agglomerációikban a szuburbanizációs jelenségek (Szirmai 2007, 742-743). Ezek a most már kivétel nélkül egyetemi városok nemcsak az explicit tudás áramoltatása és átadása terén játszanak jelentős szerepet, hanem a hallgatólagos tudás átadásának is elsődleges színterei. Minthogy ez a fajta tudás elsősorban a személyek közötti kapcsolatok révén terjed tovább, ezért a személyek közötti találkozások és érintkezések gyakoriságának nagy jelentősége van. A személyes és hallgatólagos tudás kellő dinamikájú átadása, áramlása kiemelkedően fontos tényező a város és a régió innovációra való fogékonyságának, arra való hajlandóságának szempontjából, sőt, a szakirodalomban már azt is hangsúlyozzák, hogy a földrajzi közelség a hallgatólagos tudás jobb megoszthatósága miatt előmozdítja az alkotókészséget és az innovációt (Desrochers 2001, 36-37). A nagyvárosokban szokásos gazdasági és kereskedelmi tevékenységből eredő forgalmon túlmenően a civil szervezetek működése is személyközi kapcsolatokkal jár, melynek során az explicit eszmék és gondolatok mellett magatartásminták és a hallgatólagos tudás más formái is terjednek. A hallgatólagos tudás cseréje és áramlása a helyi társadalom finomerezetén keresztül zajlik, amely egyben új kapcsolathálók létrehozására ösztönöz, illetve ilyeneket készít elö. Noha a helyi nyilvánosság elsősorban a tudás explicit formáinak cseréjében játszik kiemelkedő szerepet, a személyközi találkozások ösztönzésével maga is hozzájárul a hallgatólagos tudás átadásához és átvételéhez. A helyi nyilvánosság hozzájárulhat az alkotást elősegítő tudáskörnyezetek kialakulásához annak mind a három szintjén: a fizikai feltételek szintjén azzal, hogy részben a tudás- és információátadás fizikai feltételeit magában foglalja és fenntartja; a társadalmi feltételekkel oly módon, hogy a helyi társadalom számos szereplöjét kapcsolatba hozza egymással; és végül kognitív módon azáltal, hogy mindenekelőtt elősegíti az explicit és a hallgatólagos tudás áramlását (Hemlin-Allwood-Martin 2004, 2-3) .

A hallgatólagos tudás terjedésének vonatkozásában a növekvő ipari és közigazgatási koncentrációk túlmutatnak önmagukon, mert felgyorsítják és kiszélesítik e tudásforma cseréjét is, és ezáltal válnak teljessé a nagyvárost dinamizáló és az innovatív megoldások irányába mozgató erőforrások. Amíg ugyanis az explicit tudás jelentős részben kivihető a nagyváros határain túlra és ott tovább adható, 
addig a hallgatólagos tudás - minthogy területhez és szituációkhoz és az ezekhez kapcsolódó személyekhez kötött - a demográfiai koncentráción belül marad és elsősorban ott fejti ki előnyös hatásait, és csak valamilyen tömeges elvándorlás hatására csökkenhet. Ezek a hatások nemcsak a munkaerő nagyobb rutinjában és a termelékenység növekedésében mutatkoznak meg, hanem az élet minden szférájában, a közigazgatásban éppúgy, mint a kulturális fogyasztás minőségében. A tudás áramlása kapcsolja össze a legmélyebben a nagyobb városokban megvalósuló különféle olyan koncentrációkat, mint az ipari, a szolgáltatási, a közigazgatási, egészségügyi és kulturális koncentrációk, és általa valósul meg ezek alkotó összhatása, egymást segítő hatása. A földrajzi közelség folytán, ami az említett módon hatékonyan elösegíti a hallgatólagos tudás cseréjét is, a tudástípusok különbözőségéből eredő, vagy azzal terhelt konfliktusok is könnyebben megoldhatók (Ponds-van Oort-Frenken 2009, 110-113). A tág értelemben vett szellemi tőke ily módon erősödik és tovább koncentrálódik, ami ismét csak olyan bázisa lesz az innovációnak, amely nem írható le csak közgazdasági jelenségként.

Az érem másik oldala az, hogy a nagyobb népsürüséget előidéző lakosságkoncentráció miatt, amely az explicit és a hallgatólagos tudás magas koncentrációjával is jár az előnyös helyzetủ régiókban, a csökkenő lakosságú régiók a munkaeröveszteségeken túlmenően a hallgatólagos tudás elvesztését, illetve nagyon alacsony szintủ áramlását is kénytelenek elviselni. Az egyik oldallal szemben, ahol sokrétüen halmozódnak az előnyök, csak egy másik regionális koncentráció lehet hatásos, ahol szintén halmozott előnyök mutatkoznak majd, melyekkel együtt jár az explicit és a hallgatólagos tudás koncentrációja is. A tudástársadalommal, ahol a tudásnak még nagyobb az értéke, szervesen velejár a tudás koncentrálódásának más előnyök halmozódását elösegítő hatása is.

\section{A nagyrégiós fejlesztési programok, a helyi nyilvánosság és a regionális innováció}

A nagyrégiós centrumot fejlesztő programok lényege, mint ismeretes, olyan növekedési pólusok (térségi koncentrációk) kialakítása, illetve a meglévők fejlesztése, amelyek képesek lendületbe hozni a körülöttük levő tágabb régiót is, elsősorban a közeli kisebb városokat és falvakat, és rajtuk keresztül a távolabbiakat is. A nagyobb városoknak, mint a fejlődést szolgáló centrumoknak a fontosságát a lisszaboni program aktualizált változata is hangsúlyozza (Lengyel 2007, 759), és a hazai szakirodalomban is kiemelik a főváros után a második szintet alkotó öt nagy vidéki város fejlesztésének fontosságát (Horváth 2007, 719). A különféle erőforrások helyi koncentrációja és megerősítése nélkül nem alakul ki a gazdasági fejlődésnek és a tudásgyarapodásnak az a kritikus tömege a gazdaság, a helyi társadalom, a tudomány és a kultúra különböző szektoraiban, mely olyan tartós fejlődést eredményezhet, amely még az országhatáron is átível. A növekedési pólusok kialakítása 
csak azáltal lehetséges, hogy a helyi társadalom tagjai felvállalják azt a viszonylagos egyenlőtlenséget, amely ilyen koncentrációk kialakításával a régión belül együtt jár. Ennek fejében régiójuk fejlődése felgyorsulhat, és ez által hosszabb távon mérséklődhet a nagyrégiók közötti egyenlőtlenség. Az ilyen programoknak megelőző funkciója is van, amennyiben lemenő spirálba kerülő régiók kialakulását előzhetik meg, illetve csökkentik az ilyen helyzetbe került kisebb térségek számát és kiterjedését.

A gazdasági érveken túlmenően a régiócentrumokat ösztönző fejlesztő programok szociológiai indokoltságát egyebek mellett éppen a fentebb felvázolt nyilvánosságfejlődési, tudásáramlási és társadalmi mobilitási folyamatok adják. A nagyobb és kisebb régiók központjaiba húzódott, magasan képzett rétegek fiatalabb csoportjai inkább képesek és hajlamosak elfogadni és keresni a technikai és társadalmi innováció különféle formáit: így ők alkotják elsősorban az innováció személyi feltételeit. Képzettségük folytán arányosan nagyobb mértékben járulnak hozzá a régiók tágabb értelemben vett identitásának meghatározásához, amelybe a történeti-kulturális identitás hagyományos dimenzióin túlmenően az életmódot markánsan meghatározó közgazdasági és földrajzi feltételek elfogadása és alkotó hasznosítása is beletartozik. A tudományos kapacitások és a régióközpontok egybeesése vagy egymáshoz nagyon közeli elhelyezkedése ugyancsak indokolttá teszi azt, hogy e regionális tudáscentrumokat egyben a technikai és társadalmi innováció központjainak tekintsük.

\section{A helyi gazdasági és kulturális identitás kialakulása}

A régiócentrumként szolgáló vidéki nagyvárosok és az egyetemek együttes fejlesztése fő irányainak összehangolására is sor került több helyen. A helyi nyilvánosság közönsége ennek részleteiről ugyan értesül, de a megállapodások jelentőségét csak hosszabb távon, a gyakorlati következmények megnyilvánulása során fogja megtudni, és tudja majd értékelni. Eme együttműködés esetén is arról van szó, hogy kijelölnek bizonyos további mozgástereket, miközben másokat pedig értelemszerüen kizárnak. Miközben kétségtelen az, hogy a vidéki tudáscentrumoknak nyitottságot teremtő és fenntartó szerepük van bizonyos fokig, de ami létrejön a fejlesztések eredményeként, az az élesedő versenyhelyzetben arra készteti a régiókat és a bennük müködő egyetemeket, vállalatokat, más intézményeket, hogy a kialakult pályákon mozogjanak, hogy annak az előnyeit maximálisan kihasználják. Pl. ha Szegeden megépül a Biopolisz, ami egy kisebbfajta városnegyeddé válik, akkor ez hosszú távra meghatározza nemcsak az adott városrész fejlődési irányát, hanem bizonyos fokig az egyetemét és a városét is. A jelentős támogatás kétségtelenül segít, de erősen meg is határoz, és így az adott régió identitását is erősen befolyásolja. E meghatározottságok értékelése és a fejlődés távlatainak felmérése vonatkozásában a helyi közösségek, a város és a régió fejlesztése iránt elkötelezett egyesületek többnyire fáziskésésben vannak, és ez tükröződik a helyi nyilvánosságban is. Mind a döntéseket előkészítő, mind pedig 
a döntéseket követő megvalósítási szakasz feldolgozásához nagy szükség van jól működő, kellően nyitott helyi nyilvánosságra.

Az új ipari, kereskedelmi, valamint kulturális, egészségügyi és sportlétesítményeknek a létrehozása a nagyrégiók központjait fejlesztő programok keretében az innováció feltételeinek további koncentrálódását jelenti: ez egyfelöl a régióközpont és a távolabbi körzetek közötti egyenlötlenség további növekedésével jár, másfelől azonban segít annak a kritikus tömegnek az elérésében, amely nélkülözhetetlen a régió központjának és vele együtt a régió egészének gazdasági, kereskedelmi és kulturális fellendüléséhez.

A helyi nyilvánosságnak kulcsfontosságú szerep jut a helyi gazdasági és kulturális identitás meghatározásában és kibontakoztatásában is. A régiófejlesztés fontos kiindulópontja lehet a térség vagy kistérségek gazdasági, valamint történelmi-kulturális identitásának pontos meghatározása és felhasználása, különösen akkor, ha az idegenforgalom előtérbe állításáról és fellendítéséről van szó. A fejlesztési pályák kijelölése, megvalósítása és fenntartása már az előbbi identitáson túl a gazdasági identitáshoz is hozzátartozik: a régiók gazdasági önmeghatározása, saját belső lehetőségeik felismerése és érvényesítése indokolttá teszi e fogalom alkalmazását, amire a regionalizmus korábbi fázisában, amikor egy régió jövőjét nagyon jelentős mértékben, ám egy kevéssé differenciált regionális politika alapján az országos központokból, a kormány hivatalaiból határozták meg, nem volt még szükség. Amint azonban kialakul a cselekvőképes helyi szereplők együttmüködése, majd konszenzusa a gazdaságfejlesztés lehetséges irányairól, úgy az együttmüködést bizonyos mértékig közvetítő, figyelő és értékelő nyilvánosság is a régió identitását meghatározó tényezők közé emelkedik. A helyi nyilvánosság, amely eleve a történeti-kulturális identitás mintái között, azok által meghatározottan múködik, tehát ugyancsak jelentős szerepet tölt be a gazdasági profil kialakításában, a helyi identitás részévé való emelésében, a kulturális önmeghatározás folyamataiban. Az identitásképző folyamatok sajátja, hogy a regionális identitás kialakulásához önmagában a tennivalók kritikus áttekintése, illetve az azokhoz való egyes hozzászólások is e folyamatok részét képezi. Ezáltal a helyi polgárok identitásaikat megélik és kommunikálják.

Az innováció elömozdítását szolgáló helyi tudásközpontok megjelenése a helyi médiákban ugyancsak erős identitásképző hatású, elsősorban ama sokrétű kapcsolatrendszer felidéződése miatt, amely ezeket az intézményeket más regionális intézményekkel összekapcsolja. Az egyetemek társadalom- és gazdaságtudományi fakultásai a tudományos kutatás eszközeivel is hozzá tudnak járulni az identitási folyamatoknak a fenti értelemben vett kibontakoztatásához, amelynek természetes részét képezi a nagyrégió és a kisebb régiók múltjának feldolgozása. 


\section{Következtetések}

A helyi nyilvánosságok felértékelődését világosan jelzik az olyan tények, mint hogy a helyi sajtó erősen háttérbe szorította az országos sajtót, hogy erősödött a helyi médiák és a hírközönségek kapcsolata, vagy hogy a helyi intézmények nagyobb gondot fordítanak a helyi sajtóval való kapcsolattartásra. A helyi nyilvánosságok megerősödésének tartós jelensége kedvező, mert a gazdasági szükségszerüség jegyében megtett fejlesztési lépéseket nemcsak támogatja, hanem a regionális innováció kibontakozásával hosszabb távon a cselekvési szabadság kiszélesedését is előmozdítja. E nyilvánosságok infrastruktúrájának határozott támogatása, fejlesztése tehát részben ugyanazon érvek alapján is indokolt, melyeket a regionális fejlesztési pólusok kialakítása mellett szokás felsorolni. Ezen túlmenően a helyi nyilvánosságok megerősödése a helyi demokrácia fejlesztése mellett annyiban az országos társadalmi és politikai nyilvánosságot is erősíti, hogy kibontakozásával közvetlenül hozzájárul a policentrikus gazdasági és társadalmi fejlődés előmozdításához is.

A helyi önerőknek a szakirodalomban gyakran szorgalmazott kibontakoztatása a gazdaság, a kultúra, az egészségmegőrzés és a környezetvédelem területén ugyancsak előfeltételezi a helyi nyilvánosság kiszélesedését és hatékony működését. Ezért a felértékelődés kedvező folyamatát nemcsak célszerü összekapcsolni a nagyrégiós és kisrégiós központok kialakításával, hanem a folyamat lendületét fenntartva, sőt megerősítve olyan elemekkel kívánatos azt kibővíteni, amelyek közvetlenül is támogatják a helyi nyilvánosságok infrastruktúrájának kibontakozását. A gazdaság, a kultúra, az egészségmegőrzés és a környezetvédelem eszközeinek helyi koncentrációja már előre vetíti azt is, hogy a közeljövőben a döntési feladatok komplexitása gyors léptékben fog növekedni. Az intézményközi és társadalmi egyeztetési folyamatok ezzel arányos kibontakozásához elengedhetetlen a helyi nyilvánosságok tudatos, célirányos fejlesztése, ami a döntéshozási mozgásterek kitágításához is jelentősen hozzájárulhat. Másrészről azzal párhuzamosan, ahogy gazdasági jellegü hálózatok alakulnak ki egy régióban, amelyek a jelentős gazdasági előnyök mellett a korrupció növekedésének veszélyét is magukban hordhatják, szükséges a nyilvánosság megerősítése a negatív hatások visszaszorítása végett is. A helyi nyilvánosságok felértékelödésével és a regionális gazdaság fellendülésével nem tartott lépést a regionális gazdasági újságírás fejlődése. Történelmi okoknál fogva és a megfelelő háttérintézmények fővárosi koncentrációja folytán a regionális gazdasági újságírás fejlesztésére kiváltképpen szükség lenne, ami közvetlenül is segíthetné a nagyrégiós központokban a gazdaság müködését és csökkentené a korrupció veszélyét. Elsősorban a nyilvánosság infrastruktúráját támogató pályázatokra és hitelekre lenne szükség.

A helyi nyilvánosságok informáltságának és reprezentativitásának fejlesztése egyaránt elengedhetetlen ahhoz, hogy a nagyobb régiók kialakításával szükségszerüen létrejövő egyenlőtlenségek csökkenjenek, illetve a helyi szereplők maguk nagyobb esélyt és mozgásteret kapjanak a saját helyzetük felmérésére és a kívánt pozícióik elérésére. A helyi nyilvánosság fejlődése teszi közérthetővé azt, hogy a helyi fej- 
lesztések mennyiben növelték a szabadságfokokat a munka, a kultúra, az egészség és a környezetvédelem világában. A helyi nyilvánosságok támogatása során jelenleg azoknak informatív oldalát is célszerü fejleszteni, hogy a lakossági csoportok szélesebb köre tudjon érdemben tájékozódni a gazdasági, szolgáltatási, egészségügyi és kulturális lehetőségekről. Ez hozzásegíti a lakosság egyes rétegeit ahhoz, hogy meg tudják fogalmazni az érdekeiket - ezáltal erősítve az adott nyilvánosság reprezentatív oldalát is.

Az egyetemek és főiskolák és más helyi tudásközpontok növekvő gazdasági és kulturális befolyása miatt indokolt lenne az eddiginél jobb pozicionálásuk a helyi nyilvánosságban. A közönségkapcsolati egységek kialakítása a nagyobb egyetemeken igen jelentős lépésnek, de csak a szemléletváltozás kezdetének tekinthető. A tudatos közönségkapcsolati munkára már csak a hallgatók toborzása miatt is egyre inkább indokolt az egyetemeknek nagyobb figyelmet fordítaniuk - ahol ez még nem történt meg. A helyi, városi lakóközösség és az egyetem viszonyát több helyen konfliktusok terhelik, amelyek megoldását a helyi nyilvánosság is elősegítheti.

A helyi nyilvánosságokban lezajló folyamatok, éppen a feltárt fontosságuknál fogva, további szociológiai kutatásokat indokolnak. Ezek közül is a legsürgetőbbek közé tartoznak azok, amelyek térben körülhatárolják az egyes helyi társadalmi tereket, meghatározzák a csomópontokat és centrumokat, valamint az átfedéseket.

\section{Jegyzetek}

${ }^{1}$ A tanulmány az MTA-PE-BME Regionális Innovációs és Fejlődéstani Hálózati Kutatócsoport kutatási programjának keretében készült. A hivatkozott empirikus eredmények egy jelentős része A vidéki tudáscentrumok régiófejlesztő hatása címü, az OTKA által támogatott kutatásból származik. Ezek elsősorban a vidéki egyetemi oktatókkal, kutatókkal, az egyetemi városok közigazgatásának vezetőivel, valamint a helyi sajtó vezetőivel készített interjúkon alapulnak.

2 A regionális lapok túlsúlya már a kilencvenes években kialakult. A Hetek. Országos közéleti napilap 2001. október 5-én megjelent cikkében írta Földvári Katalin: „A Marketing Centrum által lapunknak készített korábbi felmérés azt mutatta, hogy a magyar lakosság 44 százaléka olvas napilapokat; a legolvasottabbak országos szinten ezen belül a megyei lapok, megelözve olyan 'lapóriásokat' is, mint a Népszabadság."

${ }^{3}$ A GFK és a Szonda Ipsos egyik legutóbbi, 2007 nyarán készült felmérése szerint „2007 első félévében a legnépszerübb fizetős (tehát nem ingyenes) laptípusnak az önállóan terjesztett müsorújságok bizonyultak, melyet megjelenésenként a felnőtt lakosság 35\%-a olvasott. A dobogóra még a megyei napilapok (31\%) és a nöi magazinok (29\%) kerültek." (Forrás: http://www.mediainfo.hu/tanulmanyok/ essay.php?id=941) A müsorújságok a szük, és valójában más médiákra utaló tartalmuk miatt nem versenytársai a széles tartalmi spektrumú megyei lapoknak, miként a női magazinok sem. Ez az adat tehát a regionális/megyei lapok elsőbbségét mutatja az országos napilapokkal szemben. Ezt a tendenciát megerősítik a Magyar Terjesztés-ellenőrző Szövetség honlapján (www.matesz.hu) megjelent legújabb, auditált adatok is 2009 harmadik negyedévéről.

${ }^{4}$ A helyi nyomtatott sajtó felértékelődésével kapcsolatos trendekről a fentebb hivatkozott OTKA kutatás keretében készült interjúkban nyilatkozó helyi vezető újságíróknak is pontos tudomásuk volt.

5 A GFK Hungária Piackutató Intézetnek az ORTT megrendelésére, 2007 elején készített felméréséből az derült ki, hogy a helyi adókat nagyobb mértékben hallgatják, mint az országos adókat (Forrás: Népszabadság 2007. április 21. 16. oldal). 
${ }^{6}$ A helyi sajtó képviselöi érzékelték és az interjúkban részletekbe menően kommentálták a másik két félnek - a helyi önkormányzat vezetőségének, de főleg az egyetem vezetőségének - azon fogyatékosságait, amelyek a helyi nyilvánossághoz és sajtóhoz való viszonyukban mutatkoztak. Ugyanakkor nincs összehasonlításuk azt illetően, hogy e viszonyok más régiókban hogyan alakultak. Az egyes régióközpontokban részben más a sajtó szerepe és befolyása is.

7 „Békés megye legnagyobb gondja, hogy nő a lakosság életkora, erősödik az elvándorlás - föleg a képzett fiatalok részéröl -, miután egyre alacsonyabb a kvalifikált munkaerőt foglalkoztató munkahelyek száma..." (A kiegyenlítódést... 2004).

${ }^{8}$ A szerzők a 2002 novemberében Koppenhágában megrendezett 'Triple Helix" konferencia anyagából válogattak. A Triple Helix konferenciák visszatérő témája a kormányzatok, az egyetemek és az ipari vállalatok közötti gazdasági és innovációs együttmüködés.

\section{Irodalom}

Angelusz R. (1983) Kommunikáló társadalom. Gondolat, Budapest.

Angelusz R. (2000a) Nyilvánosság és társadalmi látásviszonyok. - Angelusz R. (2000) A láthatóság görbe tükrei. Társadalomoptikai tanulmányok. Új Mandátum, Budapest. 9-38. o.

Angelusz R. (2000b) Az új kommunikációs technikák és a nyilvánosság. - Angelusz R. A láthatóság görbe tükrei: társadalomoptikai tanulmányok. Új Mandátum, Budapest. 59-77. o.

Bartke I. (2007) A társadalom és a gazdaság települési (térbeli) koncentrációja, ennek hatásai és megítélése. - Magyar Tudomány. 6. 730-739. o.

Beluszky P. (2007) A regionális központok kialakulása Magyarországon. - Magyar Tudomány. 6. 721-729. o.

Hemlin, S.-Allwood, C.M.-Martin, B.R. (2004) What is a Creative Knowledge Environment? - Hemlin, S.Allwood, C.M.-Martin, B.R. (eds.) Creative Knowledge Environments. The Influences on Creativity in Research and Innovation. Edward Elgar, Cheltenham-Northampton. 1-28. o.

Desrochers, P. (2001) Geographical Proximity and the Transmission of Tacit Knowledge. - The Review of Austrian Economics. 1. 25-46. o.

Horváth Gy. (2007) Régióközpontok Európában. - Magyar Tudomány. 06. 704-720. o.

A kiegyenlítődést segítő európai uniós programokra lenne szükség. Erősödik a fiatalok elvándorlása. (2004) http://www.vg.hu/index.php?apps=cikk\&cikk=73718 2004. dec. 15.

Lengyel I. (2007) Fejlesztési pólusok, mint a tudásalapú gazdaság kapuvárosai. - Magyar Tudomány. 6. 749-758. o.

Mészáros G. (2002) Településfejlesztési célú nonprofit szervezetek. KSH, Budapest.

Ponds, R.-van Oort, F.-Frenken, K. (2009) Internationalization and regional embedding of scientific research in the Netherlands. - Varga, Gy. (ed.) Universities, Knowledge Transfer and Regional Development. Geography, Entrepreneurship and Policy. Edward Elgar, Cheltenham (UK) - Northampton (MA, USA). 109-137. o.

Rechnitzer J. (2007) Az európai regionális politika és városfejlődés. - Magyar Tudomány. 6. 692-703. o.

Szirmai V. (2007) A magyar nagyváros térségek társadalmi jellegzetességei. - Magyar Tudomány. 6. 740-748. o. 


\section{REGIONAL INNOVATION AND THE CONSOLIDATION OF LOCAL PUBLIC SPHERES}

\section{MIHÁLY SZÍVÓS}

The starting point of the paper is that the local public spheres in Hungary became more important as a consequence of the building up of the local institution systems of democracy, and especially of the emergence of civil society, as well as of the support of regional development by the state and the EU. The growing interest for the local topics is indicated by the consolidation of local newspapers, internet forums and broadcasting corporations at the expense of the national newspapers, forums and broadcasting corporations. The civil organizations established in order to foster the development of settlements and regions have integrated into the local political life at the expense of national political parties, and they could make their representatives elected in local municipal elections. The evolvement and strengthening of the local public sphere, appearing in these forms, ensure the dialogues, debates, conflictsolving and cooperation of the economic and social actors of the smaller and bigger regions, which want to shape the future of their regions. This considerable strengthening of local public spheres establishes the future development of settlements and regions on the basis of decisions of local population, as well as the evolution and implementation of the regional innovation, including the specification of the local economic and social identity. In the context of regional innovation, the paper analyzes the effects of the geographical and social mobility of young people who search for jobs and take part in the higher education, with special regard to the emergence of development centres and their innovative role in different regions. The strengthening of local public spheres and the establishment of development and innovation centres are accompanied by the flow and accumulation of explicit and tacit knowledge, fostered also by the geographical and social mobility. 


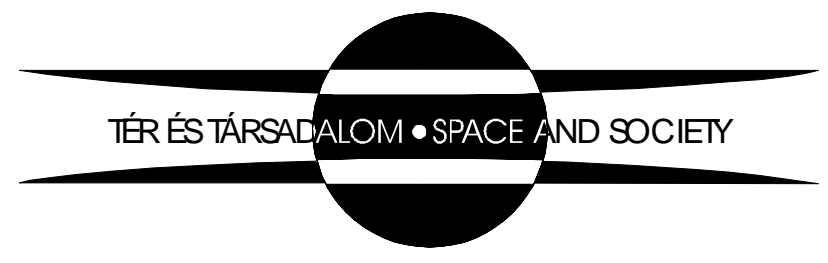

